\title{
THE FORMATION OF SEPARATE RISK MANAGEMENT COMMITTEE AND THE EFFECT ON MODIFIED AUDIT REPORT
}

\author{
SUHAIMI ISHAK \\ MOHD 'ATEF MD YUSOF \\ School of Accountancy \\ UUM College of Business \\ Universiti Utara Malaysia
}

\begin{abstract}
The aim of the paper is to examine the formation of a separate risk management committee (RMC) and its effect on the modified audit report among the non-banking and financial companies listed in Bursa Malaysia. Data was collected from the annual reports of a sample of 300 companies from 2004 until 2009. Both descriptive and multivariate analyses were employed to address the research objectives. The results indicate that a separate RMC is negatively related with the acceptance of the modified audit report. Further, the RMC's members with independent non-executive status and members with accounting and financial background will also probably reduce the acceptance of the modified audit report. However, losses recorded for previous financial years are likely to increase the issuance of modified audit report by the auditor. The period of auditor engagement with the client and client size will also affect the modified audit report. The findings provide empirical evidence on the development and importance of a separate RMC for the modified audit report.
\end{abstract}

Keywords: Separate risk management committee, modified audit report, Malaysia.

\section{Introduction}

Generally, in the risk management committee structure are the risk management function combined with the audit committee (known as combined RMC) and the existence of separate risk management committee (known as separate RMC) both of which are the sub-committees of the board of directors (BOD). The objective of this study is to examine whether the existence of a separate RMC gives any effect on the modified audit report particularly on risk issues. Traditionally, the audit committee performs the risk management function (Yatim, 2009) and it is a challenge to this committee to add a new job portfolio. Whereas, Zaman (2001) added that it was unreasonable to expect the audit committee to perform a new job given their lack of time and expertise. Risk management is not only involved in the risks of performing financial statements and internal control system for which the audit committee has expertise on this routine job but risk management involves the risks surrounding the external business operation and its viability such as marketing risk and competition risk. As the result, the formation of a separate RMC which focuses only on the risks profile of the company will be seen a help to manage the risks effectively and to improve company performance (Liew, Mat Zain, \& Jaffar, 2012). 
Further, Subramaniam, McManus and Zhang (2009) added that an effective risk management was seen to enhance the quality of financial reporting, achieve the company's objectives as well as safeguard its reputation. Iyengar, Land and Zampelli (2010) argued that the board's committee had the implication and the influence on the quality of financial reporting. The formation of a separate RMC focusing on the broad areas of risks including internal and external risks will help the company in managing those risks without depending only on the audit committee. Some expertise on the company business's external environment is needed in a separate RMC rather than depend on the audit committee members who have the expertise in internal control and accounting transactions. For example, separate RMC members with expertise on business opportunity and investment will evaluate the company's viability in future and reduce the risks of going-concern. This situation will reduce the acceptance of the modified audit report by the company.

Although the RMC is strongly recommended, its formation is still voluntary and not mandatory in most countries in the world including Malaysia. Combined Code, FRC (2006) and Malaysian Code on Corporate Governance (MCCG (2007; 2012) have clearly stated that the BOD has its principal responsibility to ensure an in-place system that effectively identifies, assesses, monitors and manages key business risks. Furthermore, at the Corporate Governance Week 2011, the chairman of the Security Commission Malaysia (2011) highlighted the to the BOD about the responsibility in the risk management process. She was concerned about the failure of the BOD to establish an appropriate measure for the risk management process in the company. The Committee of Sponsoring Organizations of the Treadway Commission (COSO) (2004; 2012) issued in its Enterprise Risk Management (ERM), an integrated framework for the ERM process. This framework involves the board and the management at all levels for risk profile of the organization. Therefore, the existence of the RMC is seen as a best measure for the risk management initiative in the company. This study offers a new insight into the relationship between the existence of a separate RMC and the modified audit report. This relationship motivates us to study more about the RMC and its effect on the modified audit report particularly on risk issues. Normally, one of the elements in a company's financial reporting is what the stakeholders such as investors, shareholders and regulators are likely to look up in the report of the auditor besides the profit, asset value and share price of the company (Ismail \& Abdul Rahim, 2011). The modified audit report indicates a company's financial reporting has a problem or views the financial report as bad.

This study contributes to the knowledge that the existence of a separate RMC gives impact to the acceptance of the modified audit report by the company. The job profile of a separate RMC focusing on the broad areas of risks can reduce the exposure of risks by the company including the external risks such as going-concern risks and competition risks. Consequently, the probability of receiving a modified audit report particularly on the risk issue is less due to the effective managing of the risk exposure to the company. Theoretically, this situation creates a linkage between the separate RMC and the modified audit report and further on the quality of financial reporting. The rest of this paper is organized as follows. Section II describes the past literature and hypotheses development. Section III provides the research methodology, followed by section IV with the analysis of the results and the discussion. Lastly, section $\mathrm{V}$ presents the conclusion and recommendation.

\section{Previous Research and Hypotheses Development}

The study on the effectiveness of the RMC and the modified audit report remains scant and limited. However, some previous studies have 
examined the relationship between the board's characteristics or the audit committee composition and the audit opinion (see Carcello \& Neal, 2000; Farinha, \& Viana, 2009; Masyitoh, \& Adhariani, 2010; Wenyao, \& Qin, 2007; Pucheta-Martinez, $\&$ Fuentes, 2007). The role of the RMC in risk management is relatively unexplored and the literature in that field is limited and scant. Tufano (1996) added that the lack of research in the risk management committee was due to the lack of a meaningful data on risk management practices. Subramniam and Carey (2011) reported that the establishment of a formalized system of risk management in an organization was a more recent development. The establishment of the $\mathrm{RMC}$ is seen to be a complement to the oversight function of the board of directors and might be able to reduce the burden of the task by the audit committee. Whereas, Fields and Keys (2003) claimed that RMCs have gained popularity as important oversight committees. Furthermore, Subramaniam et al. (2009) added that the existence of a separate RMC focusing on the risk profile was also able to increase the quality of internal monitoring and quality of financial reporting in relation to risk management. While Iyengar et al. (2010) supported the idea that the board committee was able to give implication on the quality of financial reporting. The existence of a separate RMC has the job profile on broad areas of risks including the internal and external risks. The external risks are more challenging due to the unexpected impacts in the future and are involved with the viability of the business. The experts and the qualified members of the RMC effectively manage those risks and reduce the exposure to these types of risks. Eventually, the likelihood of the company receiving the modified audit report in relation to these risks is reduced and increases the quality of the company's financial reporting. The establishment of a separate or a stand-alone RMC is also seen as being able to implement its oversight function for the risk management profile of the company. Compared to the other board committees such as the audit committee, it has a lot of duties on internal control and accounting transactions. It has no time to evaluate the detail on the external risks such as business opportunity, marketing and completion risks. The lack of expertise among the members of the audit committee in the business industry and the investment opportunity makes it difficult to evaluate these types of risks (Zaman, 2001). Thus, the hypothesis is generated as follows:

H1: The existence of a separate or distinct RMC is negatively associated with the probability that the company will receive the modified audit report.

The researchers also included some other factors that contribute to the acceptance of the modified audit opinions by a company such as whether they are the RMC's characteristics or other factors. The researchers considered the independence of the RMC (RMCINDE), qualifications of RMC (RMCQUAL), loss (LOSS), auditor tenure (AUTEN) and client size (CLSIZE).

Composition of the individuals who serve on the board is an important element in creating a board that is an effective monitor on risk matter. The board's oversight committee is seen to be more efficient if the members come from the outside or are independent members because these people have the reputation of being experts (Fama \& Jensen, 1983). The monitoring and oversight function performed by this type of members tends to be more adhered to the related approved standards, laws and regulations, and any violation of such standards and requirements only creates a negative perception among the outside firms that are interested in their expertise (Carcello \& Neal, 2000). This is consistent as in the agency theory view where outside or independent directors will be able to monitor any self-interested actions by the managers to lower agency cost (Nicholson, $\&$ Kiel, 2007). A current practice for audit committees in Malaysia, (MCCG, 2007; 2012) is that all the members should be non-executive members and the committee should encompass at least three members. While for the composition of the BOD, in the United Kingdom (UK), the 
Combined Code, FRC (2010) recommends that at least half of the board, excluding the chairman, should comprise independent nonexecutive directors (INEDs) while the Australian Securities Exchange (2010, 2nd edition), the Corporate Governance Council explains that the majority of the board should be independent directors. Xie, Davidson III, and DaDalt (2003) exposed that the non-executive board members reduced the probability of the company receiving accounting fraud and this study is consistent with the literature of Klein, 2002; Beasley, 1996; Peasnell, Pope, and Young, 2005. However, Wenyao, and Qin (2007) found insignificant relationship between independent board members and the modified audit opinion. Hence, the independence of the RMC (RMCINDE) is expected to have a negative relationship with the probability of the company receiving a modified audit opinion.

The possession of academic backgrounds such as accounting and finance as well as industryspecific knowledge by the board members would enable them to better understand the company's issues and problems (Roberts, McNulty, \& Stiles, 2005) and Md Yusof (2010) argued that an audit committee with a higher proportion of financial experts would lead to credible financial reporting.

The ability to govern also depends on the knowledge and skill owned by the board members (Lorsch, 1995) and the argument is supported by (Pettigrew \& McNulty, 1995) that to be effective in monitoring strategic decisions, directors should be individuals with relevant knowledge and expertise. Yatim (2009) suggested that the audit committee members with finance or accounting backgrounds have a better understanding of risk management activities and can engage more actively in the risk management process. DeZoort and Salterio (2001) supported the idea that board members with finance and accounting backgrounds have a better understanding of the auditing issues including risk awareness and risk detection. Further,
Carcello and Neal (2003) argued that a financial expert would be more effective in supporting the auditor's decision to issue going-concern opinions. Further, RMC members with finance and accounting backgrounds (RMCQUAL) would be expected to have an effect on the duties they are performing especially in relation to risk awareness and risk identification.

If a company reports consecutive losses, this will be likely to have an impact on the auditor's opinion (Farinha \& Viana, 2009). They have proved this argument in their study that the existence of consecutive losses has a positive impact on the issuance of a modified report by the auditor. This is also consistent with the study done by Pucheta-Martinez and Fuentes (2007) that the company which reported losses in the previous year has a positive relationship with the chance to receive a qualified audit report in the current year. Companies that reported consecutive losses will be characterized by greater financial risks and even modified opinions will be issued. Thus, it is expected that there is a positive relationship between consecutives losses (LOSS) and the current modified audit report.

According to Shockley (1982), a long relationship between the client and the auditor would lead to less rigorous scrutiny and blind reliance on the client. Also, Vanstraelen (2000) reported a long relationship reduced the auditor's willingness to issue a qualified audit report. Al-Thuneibat, Ai Issa and Ata Baker (2011) supported the idea that the long audit tenure affected the audit quality performed by the auditor. Some researchers have studied the effectiveness of rotation or mandatory rotation of the external auditor. For instance, Lu and Sivaramakrishnan (2009) examined the effect of mandatory audit firm rotation on the company's investment decision while Kaplan and Mauldin (2008) investigated the relationship between audit firm rotation and independence-related perception. The result of this study revealed that audit firm rotation does not strengthen independent appearances among non-professional investors. In terms of 
audit quality, Jackson, Moldrich and Roebuck (2008) found that mandatory audit firm rotation does not improve the audit quality and auditor independence. In this study, the researcher expected that there would be a negative relationship between auditor tenure (AUTEN) and the modified audit report.

The size of the client may influence the auditor for the issuance of an audit opinion (PuchetaMartinez \& Feuntes, 2007). They argued the risk of damage to the auditor's reputation and the risk of litigation to the auditor. Hence, a more independent audit approach would be absorbed and more likely a modified audit report will be issued. However, McKeown, Mutchler and Hopwood (1991) found a negative relationship between client size and the receipt of a qualified audit report. This finding was supported by the next few studies (see Carcello, Hermanson, \& Huss, 1995; Mutchler, Hopwood, \& McKeown, 1997). Nevertheless, the researcher expected a positive relationship between client size (CLSIZE) and the issuance of a modified audit report by the auditor.

\section{Research Methodology}

We used the logistic regression analysis to examine the relationship between the modified audit report and the variables proposed for the existence of a separate RMC. The model used to test the hypotheses is as follows:

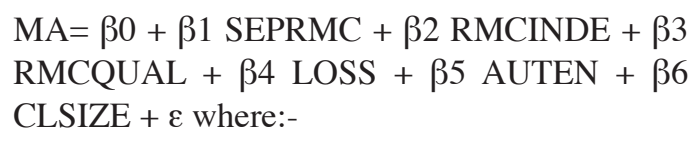

MA

-Modified Audit Report 1, if received modified audit, otherwise 0

\section{SEPRMC -Separate RMC}

1 , if there is the existence of a separate $\mathrm{RMC}$, otherwise 0
RMCINDE

-RMC Independence proportion of independent non-executive members on the RMC

RMCQUAL -RMC Qualification proportion of RMC members with accounting or finance qualification

$\begin{array}{ll}\text { LOSS } & \begin{array}{l}\text {-Loss } \\ 1, \text { if the company reported loss } \\ \text { in either or both of the two } \\ \text { previous years, otherwise } 0\end{array} \\ \text { AUTEN } & \begin{array}{l}\text {-Auditor Tenure } \\ \text { number of years of engagement } \\ \text { with the same audit firm }\end{array} \\ & \begin{array}{l}\text {-Client Size } \\ \text { natural log of total assets (in } \\ \text { millions of Ringgit Malaysia) }\end{array}\end{array}$

\section{Variable Definition and Measurement}

According to Aren et al. (2009) there are five types of audit reports, namely standard unqualified or clean audit report, unqualified with explanatory paragraph or modified wording, qualified, adverse and disclaimer audit report. For the purpose of this study, the unqualified with explanatory paragraph (modified wording), qualified (except for), adverse and disclaimer audit report are classified as modified audit reports. If a company received a modified audit report, the data is valued as ' 1 ' in the worksheet and if a company received the audit report other than the modified audit report, the value of ' 0 ' is coded accordingly.

The researcher considers that there is the existence of a separate RMC if the committee has a single committee with the title of 'risk management committee' without any combination with any other committee including the audit committee. Any combination of tasks and responsibility of risk management with other committees' tasks 
are considered as non- existence of a separate RMC (Combined RMC). For the purpose of this study, if the company has a separate RMC, it is coded as ' 1 ' and if a company does not have a separate RMC, the value of ' 0 ' is coded. This criterion has been used by previous studies such as Subramaniam et al. (2009) and Yatim (2009).

RMC independence refers to the number of independent non-executive members on the RMC. The data can be accessed through the directors' profiles and the composition of the RMC in the company's annual report. The number of independent non-executive members is divided by the total number of RMC members and then the proportion number is generated (see Fama \& Jensen, 1983; Farinha \& Viana, 2009; Pucheta-Martinez \& Fuentes, 2007).

For RMC qualification, the researcher has carefully read the directors' profiles to identify the qualification of the RMC members. For this study, the researcher has looked up the formal accounting or financial educational background of the RMC members and their academic level with at least a bachelor's degree and above. The proportion figure is generated by the total number of RMC members with the said qualification divided by the total number of members sitting on the RMC (see Yatim, 2009).

Loss in this study refers to the consecutive losses recorded by a company and the term of consecutive losses in this study refers to the last two years a company has recorded losses. The data of loss can be accessed through the profit and loss statement or the income statement in the financial statement. The researcher coded with a dummy of ' 1 ' for the company which reported loss in either or both of the two previous financial years and coded a dummy of ' 0 ' for otherwise. Farinha and Viana (2009) and Pucheta-Martinez and Fuentes (2007) have applied this rule in their studies.

For the auditor tenure, the researcher has reviewed the companies' annual report for every financial year for the duration of the period of the population and the sample selected in this study which is from 2004 until 2009. The researcher has identified how many years the company has engaged the same audit firm. The number of years of engagement with the same audit firm was keyed into the worksheet. This measurement was also applied by the previous studies such as by Pucheta-Martinez and Fuentes (2007).

Client size was also adopted as a control variable in this study. For the purpose of this study, the researcher decided to measure the variable by looking at the total assets owned by the company. The total assets were valued in Ringgit Malaysia (RM) since the Malaysian public- listed companies use RM for all the transactions and records. The data of total assets was accessed through the balance sheet statement and the value was entered into the worksheet. The use of this variable and measurement has been practiced by Pucheta-Martinez and Fuentes (2007) and Carcello and Neal (2000).

\section{Data Collection and Sampling Procedure}

The population frame for this study is all the public-listed companies excluding the banking and the financial institutions listed in Bursa Malaysia's website from the period of the financial years from 2004 until 2009. Based on the data gathered through Bursa Malaysia's website, there were approximately more than 130 companies with modified audit reports for the same period (2004-2009) and there were more than 200 companies which had a separate or a stand-alone RMC disclosure for the said period (Bursa Malaysia's website, 2012; Yatim, 2009; 2010). The banking and financial institutions were omitted from the sample as the nature and regulations of these firms were significantly different from the non-financial companies. The public-listed companies were chosen for this study. The public-listed companies have published their annual reports that are publicly available and could be accessed through Bursa Malaysia's website. 
A match-sampling approach was adopted as a control procedure (see Ballesta \& Garcia-Meca, 2005; Wenyao \& Qin, 2007; Sekaran, 2003). Firstly, the researcher selected the companies with modified audit reports for the period of study (2004-2009). Then, they were matched to the control samples which had clean audit reports based on the conditions that the paired companies were in the same industry, most similar in company size (total assets) and in the same period of the financial year (Ballesta \& Garcia-Meca, 2005; Wenyao \& Qin, 2007). To keep reliable and independence, once a control company has been matched to the corresponding company in the test sample in a particular year, it was not allowed to be matched again with another company (test sample) in another year (Ballesta \& Garcia-Meca, 2005). Besides, any company which never stated whether it was separate or a combined RMC or risk management matters, was dropped from the sample list. Lastly, in this study, 150 samples with modified audit opinions were gathered and matched with 150 samples with clean audit opinion. Therefore, the total number of samples in this study was 300 .

\section{Analysis of Result and Discussion}

\section{Descriptive Statistics for Samples}

Table 1 presents the descriptive statistics result for all the companies, modified audit opinion companies and clean audit opinion companies together with the result of the t-test. For the variable of Separate RMC (SEPRMC), the result shows an average of 13 per cent from the samples having separate RMCs for all the companies but for the modified audit opinion companies, the result shows only 6 per cent of the samples having separate RMCs while for clean audit opinion companies the result shows an average of 20 per cent of the samples having separate RMCs. As expected earlier, the percentage of companies with separate RMCs is larger in clean audit opinion companies due to the characteristic of the separate RMC and its function. The Independent t-test for the variable of Separate RMC shows a statistically significant level of $\mathrm{p}<0.01$. It is means that there is a significant difference in the average for this variable between two different sets of samples (modified and clean audit opinion companies).

For RMC Independence (RMCINDE), the mean for modified audit opinion companies is 75 per cent while for clean audit opinion companies it is 78 per cent. The higher percentage in clean audit opinion companies is expected because of the features and the status owned by the independent RMC members. For the sample of all the companies, the result reports that 76 per cent of the RMC members are of independent non-executive status. The comparison of mean (t-test) for this variable is significant the 10 per cent level (2-tailed) with the indication that there is a significant difference in average for the variable of RMC Independence.

The descriptive analysis also reports for the variable of RMC Qualification (RMCQUAL). In sample of modified audit opinion companies, the mean or average value is recorded at 37 per cent while for the group of clean audit opinion companies, the average value is 39 per cent. On the average, more RMC members in clean audit opinion companies have accounting or financial academic background compared to the sample of modified audit opinion companies. However, the difference of the mean for this variable between the modified and the clean audit opinion companies is statistically not significant. There is no significant or large difference in the mean value for this variable.

For the variable of Loss (LOSS), the result shows an average of 81 per cent for the samples of modified audit opinion companies that recorded loss in the previous financial year. But, in the clean audit opinion companies, only 44 per cent or below of the samples recorded loss in the previous financial year. This huge difference was expected by the researcher as the previous losses recorded by the companies have more impact 
on the current financial year. For the all the companies, the mean value reports 62 per cent. The t-test is also records a significant difference $(p<0.01)$ for the mean between the modified and clean audit companies.

The modified audit opinion companies record a maximum of 10 years of engagement (AUTEN) with the same audit firm while the clean audit opinion companies, the maximum period of engagement is 11 years. For the mean or the average value for these two groups of samples, the result shows about 4 years of engagement with the same audit firm. The t-test the result shows that there is a statistically significant difference at the level of 10 per cent (2-tailed) for this variable.

For the variable of client size (CLSIZE), the modified audit opinion companies have RM 230 million on average for the total asset owned while the clean audit opinion companies have only an average of RM 184 million of assets. For the difference of the mean or the average between these two groups of samples, the t-test result recorded significant at the 10 per cent level.

\section{Correlation Analysis (Pearson Correlation Matrix) for Variables}

Table 2 reports the result of correlation among the variables. The correlations are quite low, generally below 0.3 except for a pair of modified audit opinion companies (MA) and loss (LOSS) which are correlated at 38 per cent with a significant level of 0.01 . It means that MA and LOSS have a quite strong relationship with the assumption that LOSS has a major effect on MA. Besides, a separate RMC also has an effect on MA with a correlation of 21 per cent and it is significant at the 0.01 level. The other variables that correlated are separate RMC and RMC Independence at 21 per cent at $(\mathrm{p}<0.01)$, a separate RMC and client size (18 per cent at $\mathrm{p}<$ $0.01)$ and the pair of auditor tenure and client size (12 per cent at $\mathrm{p}<0.05)$. The rest of the variables are not correlated to each other. The result also reveals that there is no higher correlation than 85 per cent which means no multicolinearity problem exists in the samples.

Table 2

Result of Correlation (Pearson Correlation Matrix)

\begin{tabular}{lcccccc}
\hline & $\begin{array}{c}\text { Modified } \\
\text { Audit } \\
\text { Opinion }\end{array}$ & $\begin{array}{c}\text { RMC } \\
\text { Independence }\end{array}$ & $\begin{array}{c}\text { RMC } \\
\text { Qualification }\end{array}$ & Loss & $\begin{array}{c}\text { Auditor } \\
\text { Tenure }\end{array}$ & Client Size \\
\hline Modified Audit Opinion & 1 & -.092 & -.063 & $.378^{* *}$ & -.085 & .095 \\
Separate RMC & & $-.211^{* *}$ & -.041 & -.027 & .095 & $.180^{* * *}$ \\
RMC Independence & 1 & .046 & -.036 & -.004 & -.112 \\
RMC Qualification & & 1 & .003 & -.089 & -.003 \\
Loss & & & 1 & -.016 & -.013 \\
Auditor Tenure & & & & 1 & $.122^{*}$ \\
Client Size & & & & & 1 \\
\hline
\end{tabular}

**. Correlation is significant at the 0.01 level (2-tailed).

*. Correlation is significant at the 0.05 level (2-tailed). 


\section{Logistic Regression Analysis}

Table 3 reports the logistic regression result. The model consists of the independent variables (separate RMC) and the control variables (RMC independence, RMC qualification, loss, auditor tenure and client size) with modified audit report as the dependent variable. The result shows the level of correct classification (the percentage of correct predictions) at 70 per cent while the Cox
\& Snell R Square and Nagelkerke R Square report at 22 per cent and 29 per cent respectively. The chi-square test reports at 74.756 and the model is significant at the level of $0.00(p<0.01)$. All the variables (independent and control variables) are significant in the expected direction.

For the hypothesis of the separate RMC (SEPRMC), it is statistically significant at the 1 per cent level with a negative sign. For

Table 3

Result of the Logistic Regressions

$\mathrm{MA}=\beta 0+\beta 1 \mathrm{SEPRMC}+\beta 2 \mathrm{RMCINDE}+\beta 3 \mathrm{RMCQUAL}+\beta 4 \mathrm{LOSS}+\beta 5$ AUTEN $+\beta 6$ CLSIZE $+\varepsilon$

\begin{tabular}{lcccc}
\hline \multicolumn{1}{c}{ Variables } & Expected Sign & & SEPRMC + CV & \\
\hline Independent Variable & & Coefficient & Wald test & p-value \\
\cline { 2 - 4 } SEPRMC & - & -1.936 & 16.748 & .000 \\
Control Variables & & & & \\
RMCINDE & - & -1.439 & 4.040 & .044 \\
RMCQUAL & - & -1.173 & 2.369 & .124 \\
LOSS & + & 1.786 & 40.479 & .000 \\
AUTEN & - & -.083 & 2.765 & .096 \\
CLSIZE & + & .002 & 6.265 & .012 \\
Constant & & .727 & 1.021 & .312 \\
Chi-square(sig) & & $74.756(.000)$ & & \\
Cox \& Snell R Square & & .221 & & \\
Nagelkerke R Square & & .294 & & \\
Clasification & & $70.3 \%$ & & \\
\hline
\end{tabular}

Variable Definition:

SEPRMC $\quad=1$, if there is the existence of a separate RMC, otherwise 0

RMCINDE $\quad=$ proportion of independent non-executive members on the RMC

RMCQUAL = proportion of RMC members with accounting or finance qualification

LOSS $\quad=1$, if the company reported loss in either or both of the two previous years, otherwise 0

AUTEN $\quad=$ number of years of engagement with the same audit firm

CLSIZE $=$ natural log of total assets (in millions of Ringgit Malaysia) 
coefficient, SEPRMC reports at more than 190 per cent and it means that if a company has a separate RMC, the probability of the company not receiving a modified audit opinion is at 190 per cent. The examples of the companies that have separate RMCs are Opcom Holdings Berhad, Bolton Berhad and Genetec Technology Berhad. The result supports the argument by Subramaniam et al. (2009) that the existence of a separate RMC focusing on the risk profile is also able to increase the quality of internal monitoring and quality of financial reporting in relation to risk management. Consequently, the likelihood of the company receiving a modified audit report, particularly for risk issues, is less. Meanwhile, Harrison (1987) reported that RMC is seen to specifically enhance the accountability of the board as it provides an independent oversight of various board activities especially on the risk issues. Due to the contribution of the RMC, Fields and Keys (2003) argued that RMC has gained popularity as an important oversight committee even though most of the countries in the world are still considering it as a reserve as mandatory requirement to form a separate RMC in the company. The result supports the proposition of the hypothesis (SEPRMC) that the existence of separate RMC will influence the company not to receive a modified audit report. This result is also consistent with the requirement of MCCG 2007 and 2012 which clearly states that the board has the principal responsibility on the risk process including the identification of the principal risk until the implementation of the appropriate system to manage those risks. Consequently, the formation of a separate RMC as a board committee is able to enhance the effectiveness of the risk oversight function by the BOD as reported in the result of this study where the existence of a separate RMC gives impact to the company not to receive a modified audit opinion.

For the control variable of RMC independence (RMCINDE), the result also shows it as statistically significant at the 5 per cent level in a negative direction as expected earlier. For coefficient, the result shows 140 per cent with the indication that if a company has a higher number of independent non-executive members on the RMC, the probability of the company not receiving a modified audit opinion is at 140 per cent. The result is consistent with the earlier study by Pucheta-Martinez and Fuentes (2007) which found a significant influence between the audit committee with more independent members and the receipt of qualification of audit report, and Xie et al. (2003) added that the non-executive board members reduced the probability of the company receiving accounting fraud. However, Wenyao and Qin (2007) found an insignificant relationship between the independent board members and the receipt of a modified audit opinion. As a conclusion, the result reveals that the independent non-executive members sitting on a RMC give affects the issuance of a modified audit opinion. This type of committee members (independent non-executive members) have the role to influence the acceptance of a modified audit opinion in terms of risk issues.

The RMC qualification (RMCQUAL) is statistically significant $(p<0.10)(2$ tailed $)$ and with a negative sign which follows the proposed direction. It is reported at more than 100 per cent for beta coefficient and it means that if the members of the RMC have accounting or financial academic background, the likelihood of the company not receiving a modified audit opinion is more than 100 per cent. The result is consistent with the argument by DeZoort and Salterio (2001) that board members with finance and accounting backgrounds have a better understanding of the auditing issues including risk awareness and risk detection. Whereas, in the audit committee Yatim (2009) suggested that members with finance or accounting backgrounds have a better understanding of risk management activities and would be able to be engaged more actively in the risk management process. Chung, Ho and Kim (2004) and Ho and Wong (2001) in their earlier studies found that the inclusion of experts in the board committee serves as a means of reducing information asymmetry, managerial 
opportunism and improving disclosure quality and enhancing the effectiveness of resources. The knowledge gained by the RMC members through the formal study of accounting and finance is an advantage to them. They have learned the internal and external treats of being a business organization as well as the strategic solution for the situations faced. They are able to monitor the risk profiles of the organization and eventually affect the auditor's concern of risk issues. Therefore, this result implies that RMC qualification has a relationship with the modified audit opinion issued by the auditor.

Next, the variable of loss (LOSS) also recorded statistically significant at the 1 per cent level with a positive sign. It provides more than 170 per cent for coefficient and it means that if a company received a loss in the previous years, there is a 170 per cent probability the company will receive a modified audit opinion in the current year. The result support the findings of the study conducted by Farinha and Viana (2009) that the existence of consecutive losses has a positive impact on the issuance of a modified opinion by the auditor. PuchetaMartinez and Fuentes (2007) also added that the which company which reported losses in the previous year has a positive relationship with the chance to receive a qualified audit report in the current year. The loss experienced by a company has an impact on the financial stability and future business operation. Eventually, there emerges the risk of going-concern to that company and from the above result, loss has an association with the modified audit opinion.

The variable of auditor tenure (AUTEN), is also statistically significant at the 10 per cent level with a lower beta coefficient has a 8 per cent (at negative sign). It indicates that if a company has a long engagement with the same audit firm, the likelihood of the company not to receive a modified audit report is only at 8 per cent. The result supports the finding of the study done by Vanstraelen
(2000) that a long relationship between the client and the audit firm will reduce the acceptance of a modified audit report. With a long engagement with the same audit firm, more improvements would have been made by the client company before the audit was made.

Lastly, the variable of client size (CLSIZE) records a significant association with the modified audit report at $\mathrm{p}<0.05$ with a positive sign as expected. For coefficient, the result presents only 0.2 per cent with the indication that the larger the assets of a company, the probability of the company receiving a modified audit report is only at 0.2 per cent. However, the result is inconsistent with the study done by McKeown et al. (1991) that client size has a negative relationship with the receipt of a qualified audit report.

\section{Conclusion and Limitations}

The result of the statistical analysis has shown some significant findings. Firstly, the result documented that the existence of a separate risk management committee (RMC) affects the issuance of a modified audit report by the auditors. The finding contributes to the knowledge and literature that the existence of a separate RMC has an implication on the acceptance of a modified audit report specifically in the Malaysian environment. The existence of a separate RMC probably will reduce the issuance of a modified audit report. Consequently, the formation of a separate RMC as a board committee is able to enhance the effectiveness of the risk oversight function by the BOD as reported in the result of this study where the existence of a separate RMC gives an impact on the company not to receive a modified audit report. The regulators and policy makers have to consider this situation. The formation of a separate RMC should be mandatory in future so as to perform the risk oversight function at the board level. 
The RMC members with the status of independent non-executives have a major effect on the acceptance of a modified audit report. The statistical result presented in this study shows that the independent non-executive members sitting on the RMC are able to influence the company not to receive a modified audit report. The oversight role played by this kind of RMC members is free from the influence of the management and is acted independently particularly for the risk profiles of the company. Looking at the current practice of the audit committee, MCCG (2007; 2012) has stipulated that all the members in the audit committee are independent non-executive members. This guideline should be applied for the RMC if a separate RMC is mandatory to be established in future.

The accounting and financial academic backgrounds of the RMC members have an influence on the receiving of a modified audit opinion. This study has documented that RMC members with accounting or financial academic backgrounds will probably reduce the acceptance of a modified audit report in relation to the risk issues. The knowledge of these members will help them in implementing the oversight role as board committee members either for internal or external risks. More attention should be given to the appointment of RMC members because the criteria of academic background is also an important factor.

Another element that affects the acceptance of a modified report is the previous loss of the company. The losses of the previous financial year are more related to the stability and the viability of the company. The auditor will consider the company's previous record and the solution in the current financial year before the professional opinion is issued. This study reveals the consequence of the company with previous loss where it will receive the modified audit report in the current year.

The engagement period between the client and the audit firm also has an impact on the receipt of the modified audit report by the client company. The long engagement between the client and the audit firm probably will reduce the acceptance of the modified audit report. The reason may be due to the improvements that have been made by the client company as a response to the auditor's concern of the previous financial year. The total assets owned by the company has a small effect on the acceptance of the modified audit report by the company. The bigger the assets owned by the company the more positive the impact for the company to receive the modified report. A small part of the organization is overlooked and causes the acceptance of the modified audit report.

This study, like other studies, has limitations. This study used secondary data as samples in which the company's annual reports were used as the main source. May be in the future, the researcher can use a different method of data collection such as interview with the auditors and the risk officers. Questionnaires also can be used by the researcher in order to collect the primary data. These types of data collection methods are important to the researcher to know some other implicit information that could be raised by the auditors or other respondents. The formation of the RMC is still voluntary and not mandatory in most countries in the world. The study for the efficiency of this board committee is limited and scant. Future study should be done on its efficiency in terms of other indications such as the company market share, profit and investment opportunity. The study should also examine the roles played by this board committee for the existence of a separate RMC and its characteristics.

\section{References}

Al-Thuneibat, A. A., Ai Issa, R. T. I., \& Ata Baker, R. A. (2011). Do audit tenure and firm size contribute to audit quality? Empirical evidence from Jordan. Managerial Auditing Journal, 26(4), 317-334. 
Arens, A. A., Elder, R. J., Beasley, M. S., Amran, N. A., Fadzil, F. H., Mohamad Yusof, N. Z., Mohamad Nor, M. N., \& Shafie, R. (2009). Auditing and assurance services in Malaysia: An integrated approach (3rd ed.). Kuala Lumpur: Prentice Hall.

Australian Securities Exchange (Amendments 2010). (2010). Corporate governance principles and recommendations (2nd ed.). Australia: ASX Corporate Governance Council.

Ballesta, J.P. S., \& Garcia-Meca,E. (2005).Audit qualifications and corporate governance in Spanish listed firms. Managerial Auditing Journal, 20(7), 725-738.

Beasley, M. S. (1996). An empirical analysis of the relation between the board of director composition and financial statement fraud. The Accounting Review, 71(4), 443-465.

Bursa Malaysia Listed Companies. (2012). Retrieved from http://www. bursamalaysia.com/

Carcello, J. V., \& Neal, T. L. (2000). Audit committee composition and auditor reporting. The Accounting Review, 75(4), 453-467.

Carcello, J. V., \& Neal, T. L. (2003). Audit committee characteristics and auditor dismissals following "new" goingconcern reports. The Accounting Review, 78(1), 95-117.

Carcello, J., Hermanson, D. R., \& Huss, H. F. (1995). Temporal changes in bankruptcyrelated reporting. Auditing: A Journal of Practice \& Theory, 14(2), 133-143.

Chung, R., Ho, S., \& Kim, J. B. (2004). Ownership structure and the pricing of discretionary accruals in Japan. Journal of International Accounting, Auditing and Taxation, 13(1), 13-20.

Committee of Sponsoring Organizations of the Treadway Commission. (2004). Enterprise risk management-integrated framework. New York: COSO.

Committee of Sponsoring Organizations of the Treadway Commission. (2012).
Enterprise risk managementunderstanding and communicating risk appetite. New York: COSO.

DeZoort,F.T., \& Salterio, S.E. (2001). The effect of corporate governance experience and financial reporting and audit knowledge on audit committee member judgments. Auditing: A Journal of Practices and Theory, 20(3), 31-47.

Fama, E. F., \& Jensen, M. C. (1983). Separation of ownership and control. Journal of Law and Economics, 26(2), 301-325.

Farinha, J., \& Viana, L.F. (2009). Board structure and modified audit opinions: Evidence from the Portuguese stock exchange. International Journal of Auditing, 13, 237-258.

Fields, M. A., \& Keys, P. Y. (2003). The emergence of corporate governance from Wall St to Main St: Outside directors, board diversity, earning management and managerial incentives to bear risk. The Financial Review, 38(1), 1-24.

Financial Reporting Council. (2006). The combined code on corporate governance. London: FRC.

Financial Reporting Council. (2010). The combined code on corporate governance. London: FRC.

Ho, S. S. M., \& Wong, K. S. (2001). A study of corporate disclosure practices and effectiveness in Hong Kong. Journal of International Financial Management and Accounting, 12(1), 75-101.

Ismail, R., \& Abdul Rahman, R. (2011). Institutional investors and board of directors' monitoring role on risk management disclosure level in Malaysia. Journal of Corporate Governance, x(2), 37-61.

Iyengar, R. J., Land, J., \& Zampelli, E. M. (2010). Does board governance improve the quality of accounting earnings? Accounting Research Journal, 23(1), 4968.

Jackson, A., Moldrich, M., \& Roebuck, P. (2008). Mandatory audit firm rotation and audit 
quality. Managerial Auditing Journal, 23(5), 420-437.

Kaplan, S., \& Mauldin, E. (2008). Auditor rotation and the appearance of independence: evidence from nonprofessional investors. Journal of Accounting and Public Policy, 27(2), 177-192.

Klein, A. (2002). Audit committee, board of director characteristics and earning management. Journal of Accounting and Economics, 33(3), 375-400.

Liew, C. L., Mat Zain, M., \& Jaffar, N. (2012). Board of directors and voluntary formation of risk management committee: Malaysia evidence. International Journal on Social Science Economics \& Art, 2(2), 67-73.

Lorsch, J. W. (1995, January/February). Empowering the board. Harvard Business Review, 107-117.

Lu, T., \& Sivaramakrishnan, K. (2009). Mandatory audit firm rotation: Fresh look versus poor knowledge. Journal of Accounting and Public Policy, 28(2), 7191.

Masyitoh, O. C., \& Adhariani, D. (2010). The analysis of determinants of going concern audit report. Journal of Modern Accounting and Auditing, 6(4), 26-37.

McKeown, J. C., Mutchler, J. F., \& Hopwood, W. (1991). Towards an explanation of auditor failure to modify the audit opinions of bankrupt companies. Auditing: A Journal of Practice and Theory, 10, 1-13.

Md Yusof, M. 'A. (2010). Does audit committee constraint discretionary accruals in MESDAQ listed companies? International Journal of Business and Social Science, 1(3), 124-136.

Mutchler, J. F., Hopwood, W., \& McKeown, J. C. (1997). The influence of contrary information and mitigating factors on audit opinion decisions on bankrupt companies. Journal of Accounting Research, 35(2), 295-310.
Nicholson, G., \& Kiel, G. (2007). Can directors impact performance? A case-based test of three theories of corporate governance. Corporate governance: An international review, 15(4), 585-608.

Peasnell, K. V., Pope, P. F., \& Young, S. (2005). Board monitoring and earning management: Do outside directors influence abnormal accruals? Journal of Business Finance \& Accounting, $32(7$ \& 8), 1311-1146.

Pettigrew, A., \& McNulty, T. (1995). Power and influence in and around the boardroom. Human Relations, 48(8), 845-873.

Pucheta-Martinez, M. C., \& Fuentes, C. D. (2007). The impact of audit committee characteristics on the enhancement of the quality of financial reporting: An empirical study in the Spanish context. Corporate governance: An international review, 15(6), 1394-1412.

Roberts, J., McNulty, T., \& Stiles, P. (2005). Beyond agency conceptions of the work of the non-executive director: Creating accountability in the boardroom. British Journal of Management, 16(1), 5-26.

Security Commission of Malaysia. (2007). Malaysian code on corporate governance (Revised 2007). Kuala Lumpur: Malayan Law Journal Sdn. Bhd.

Security Commission of Malaysia. (2011). Corporate governance week 2011. Kuala Lumpur: SC.

Security Commission of Malaysia. (2012). Malaysian code on corporate governance (Revised 2012). Kuala Lumpur: Malayan Law Journal Sdn. Bhd.

Sekaran, U. (2003). Research methods for business: A skill building approach (4th ed.). New York: John Wiley \& Sons.

Shockley, R. A. (1982). Perception of audit independence: A conceptual model. Journal of Accounting, Auditing \& Finance, 5(2), 126-143.

Subramaniam, N., \& Carey, P. (2011). Risk management, governance and assurance. Managerial Auditing Journal, 26(7). 
Subramaniam, N., McManus, L., \& Zhang, J. (2009). Corporate governance, firm characteristics and risk management committee formation in Australian companies. Managerial Auditing Journal, 24(4), 316-339.

Tufano, P. (1996). Who manages risk? An empirical examination of risk management practices in gold-mining industry. Journal of Finance, 51(4), 1097-1137.

Vanstraelen, A. (2000). Impact of renewable long-term audit mandates on audit quality. The European Accounting Review, 9(3), 419-442.

Wenyao, L., \& Qin, L. (2007, Sept). Board of director composition and audit opinions. Paper presented at the international conference on wireless communication, networking and mobile computing, Shanghai.
Xie, B., Davidson III, W. N., \& DaDalt, P. J. (2003). Earnings management and corporate governance: The role of the board and the audit committee. Journal of Corporate Finance, 9(3), 295-316.

Yatim, P. (2009). Audit committee characteristics and risk management of Malaysian listed firms. Malaysian Accounting Review, 8(1), 19-36.

Yatim, P. (2010). Board structure and the establishment of a risk management committee by Malaysian listed firms. Journal of Management \& Governance, 14(1), 17-36.

Zaman, M. (2001). Turnbull-generating undue expectations of the corporate governance, role of audit committee. Managerial Auditing Journal, 16(1), 5-9. 